\title{
Carotid intima media thickness with no cardiovascular disease in HIV-infected patients correlates with a hyperactivated/pro-apoptotic T-cell phenotype

\author{
C Tincati*1, GM Bellistrì ${ }^{1}$, M Casana ${ }^{1}$, EM Merlini ${ }^{1}$, L Comi ${ }^{1}$, M Olivetti ${ }^{1}$, \\ F Bai ${ }^{1}$, B Teresa ${ }^{1}$, A Gori ${ }^{2}$, A d'Arminio Monforte ${ }^{1}$ and GM Marchetti ${ }^{1}$
}

Address: ${ }^{1}$ Ospedale San Paolo, University of Milan, Milan, Italy and ${ }^{2}$ San Gerardo Hospital, Univeristy Monza-Bicocca, Monza, Milan, Italy

* Corresponding author

from Ninth International Congress on Drug Therapy in HIV Infection

Glasgow, UK. 9-13 November 2008

Published: 10 November 2008

Journal of the International AIDS Society 2008, I I (SuppI I):P97 doi:I0.II86/I758-2652-II-SI-P97

This abstract is available from: http://www.jiasociety.org/content/II/SI/P97

(C) 2008 Tincati et al; licensee BioMed Central Ltd.

\section{Background \\ HIV-infected patients may be at increased risk of cardio- vascular disease (CVD), and present higher carotid intima media thickness (IMT) compared with healthy controls. Besides clinical and metabolic factors, atherosclerosis in HIV is influenced by immune and inflammatory parame- ters. Given that T-cell activation correlates with CVD and HIV accounts for heightened T-cell hyperactivation, we hypothesized that early IMT increases associate to T-cell hyperactivation.}

\section{Methods}

We performed a cross-sectional correlation between carotid IMT and immunological parameters on a cohort of 71 HIV patients: 17 subjects had a positive history for cardiovascular events (CE), 22 patients presented increased IMT measurements ( $>1 \mathrm{~mm}$, IIMT), and 32 had normal IMT values $(<1 \mathrm{~mm}$, NIMT). No clinical signs of CVD were shown in the IIMT and NIMT groups. Parameters of T-cell homeostasis (CD127), activation $(\mathrm{CD} 38+\mathrm{CD} 8+)$ and death (CD95/Fas) were assessed by flow cytometry. Plasma IL- 6 and TNF- $\alpha$ levels were also measured.

\section{Summary of results}

The three groups were comparable in terms of CVD risk factors, and HIV-related viro-immunological parameters. Major results are shown in Table 1. Compared to NIMT subjects, CE patients presented higher activated
CD38+CD8+ $(\mathrm{p}=0.01)$, lower CD95+CD8+ and CD127+CD8+ cells $(\mathrm{p}=0.03)$ and increased plasma IL-6 $(\mathrm{p}=0.02)$ and TNF- $\alpha$. Surprisingly, IIMT patients presented CD38+CD8+ proportions comparable to CE $(\mathrm{p}=$ $0.18)$, significantly higher than NIMT $(\mathrm{p}=0.01)$, resulting in a significant positive correlation between IMT and Tcell activation $(\mathrm{p}=0.04)$. Analogously, IIMT patients displayed CD95+CD8+ and CD127+CD8+ proportions comparable to CE ( $p>0.5)$, and significantly lower than $\operatorname{NIMT}(\mathrm{p}=0.08$ and $\mathrm{p}=0.03$, respectively).

\section{Conclusion}

Despite no overt sign of CVD, HIV-infected patients with pathologic IMT increases display a peripheral T-cell immune phenotype and activation similar to CVD patients characterised by a highly activated/senescent, pro-apoptotic T-cell pool. By showing specific T-cell patterns associated to IMT increases, our findings support a possible role of immunological parameters as early surrogate markers of CVD risk in HIV-infected patients. 
Table I:

\begin{tabular}{|c|c|c|c|}
\hline & CE $(n=17)$ & IIMT (n = 22) & NIMT $(n=32)$ \\
\hline Left carotid IMT (mm) & $0,9(0,6-1,26)$ & $1,2(0,6-1,86)$ & $0,86(0,6-0,9)$ \\
\hline Right carotid IMT (mm) & $0,92(0,73-1,38)$ & I,24 (0,99-I,75) & $0,89(0,75-0,99)$ \\
\hline CD38+CD8+ \% & $\mathrm{I}, 5(\mathrm{I}-8)$ & $2(I-6)$ & I $(0-6)$ \\
\hline $\mathrm{CD} 38+\mathrm{CD} 8+\mathrm{n}$ & $20(11-192)$ & $28(8-84)$ & $16(0-65)$ \\
\hline CD95+CD8+ \% & $I(I-9)$ & $I(I-9)$ & $2(I-3)$ \\
\hline CD95+CD8+ n & $22(11-64)$ & $24(13-68)$ & $26(11-336)$ \\
\hline CDI27+CD8+ \% & $12(8-2 \mid)$ & $12(5-23)$ & $14(8-23)$ \\
\hline $\mathrm{CD} 127+\mathrm{CD} 8+\mathrm{n}$ & $173(121-286)$ & $202(64-364)$ & $247(108-572)$ \\
\hline IL-6 (pg/mL) & $1,5(0,2-2,2)$ & $0,8(0,4-7,4)$ & $0,88(0,24-8,3)$ \\
\hline TNF- $\alpha(p g / m L)$ & $3,2(2,3-4,7)$ & $1,6(1,5-2,9)$ & $1,5(1,27-2,10)$ \\
\hline
\end{tabular}

Publish with Biomed Central and every scientist can read your work free of charge

"BioMed Central will be the most significant development for disseminating the results of biomedical research in our lifetime. " Sir Paul Nurse, Cancer Research UK Your research papers will be:

- available free of charge to the entire biomedical community

- peer reviewed and published immediately upon acceptance

- cited in PubMed and archived on PubMed Central

- yours - you keep the copyright 